\title{
Modernizarea limbii române literare în concepția lui G. Ivănescu
}

\author{
Cătălin Nicolau ${ }^{\circledR \star}$ \\ Facultatea de Litere, Universitatea „Alexandru Ioan Cuza”, Bd. Carol I 11, 700506 Iași, România
}

\section{Despre articol \\ Istoric:}

Primit 15 aprilie 2020

Acceptat 6 mai 2020

Publicat 10 iunie 2020

Cuvinte-cheie:

dialect literar

limbă literară

modernizare

text rotacizant

\begin{abstract}
Rezumat
Studiul nostru prezintă sintetic principalele idei al lui G. Ivănescu cu privire la noțiunea de limbă literară, în general, și procesul de modernizare a ei, în mod special. Acest demers este o componentă a unei analize mai ample a concepției diacronice ivănesciene, pe care am întreprins-o în ultimii ani. Ca urmare, conceptul de limbă literară este abordat aici dintr-o perspectivă holistică, cea a întregii istorii a limbii române, căreia i se și subsumează, de altfel. De aceea, unele elemente ale limbii de cultură sînt raportate la istoria limbii vorbite și la principiile de cercetare a acesteia.

Scopul pe care îl avem în vedere este cel de a evidenția originalitatea acestei concepții, divergente față de cea a școlii bucureștene, în contextul unui interes din ce în ce mai redus faţă de lingvistica diacronică, în favoarea celei sincronice. Ivănescu reușește să construiască o teorie lingvistică originală, bazată pe argumente de ordin istoric și socio-lingvistic, ce aprofundează, completează şi, uneori, chiar contrazice, concepțiile predecesorilor și contemporanilor săi.
\end{abstract}

\section{Introducere - noțiunea de limbă literară}

În acest studiu, ne propunem să prezentăm modul în care G. Ivănescu a înțeles procesul de modernizare a limbii române literare. Acest fenomen este, însă, unul complex, iar descrierea viziunii cercetătorului ieșean asupra acestuia necesită frecvente trimiteri și la alte probleme de limbă literară, cum ar fi însăși noțiunea de limbă de cultură, precum și periodizarea istoriei acesteia.

Potrivit lui Ivănescu, limba literară reprezintă varietatea unei limbi istorice utilizată în textele scrise, indiferent de specificul conținutului lor. Este o viziune diferită de cea a lui Ion Gheție, care consideră că ar trebui făcută distincția între textele literare și cele neliterare (vezi Gheție, 1975, p. 65-66). Potrivit acestui din urmă cercetător, ar trebui avute în vedere doar textele literare, adică doar acele texte prin care se săvîrșește un act de cultură, ceea ce scoate din discuția pe marginea limbii literare texte precum documentele cu caracter privat (însemnările curente, scrisorile etc.).

Limba literară sau comună este considerată de Ivănescu o culme a evoluției unei limbi istorice: „limbile literare ... sînt tocmai ce e mai important în viaţa limbilor. O limbă ị̂si ajunge viaţa ei cea mai înaltă numai atunci cînd a devenit limbă literară” (Ivănescu, 1947, p. 2). Așadar, dezvoltarea unei variante literare a unei limbi demonstrează atingerea unui stadiu maxim al evoluției ei și, în acelaşi timp, al capacităților ei de expresie.

Ca orice dialect, limba literară are și ea o evoluție istorică proprie, însă aceasta, după savantul ieșean, trebuie separată de cea a graiurilor populare, întrucît stă sub semnul acțiunii altor factori. Motivul este acela că limba de cultură și graiurile populare sînt, prin natura lor, distincte, avînd fiecare o evoluție separată, specifică, după principii proprii. Mai exact, dacă limbile populare evoluează sub acțiunea celor trei factori principali (baza articulatorie, baza psihologică și structura socială), dezvoltarea limbii de cultură este dirijată doar de acțiunea factorului social. Practic, și apariția, și dezvoltarea limbii literare sînt explicate de Ivănescu prin structura socială și specificitatea culturală ale comunității lingvistice care o utilizează. O altă diferență între limbile populare și cele de cultură este dată de faptul că cele dintîi au o dezvoltare

*Adresă de corespondență: catalin_george2001@yahoo.com. 
involuntară, caracterizată de inovații neintenționate, în timp ce în cazul limbilor literare un rol important îl are factorul voință. O limbă literară ajunsă la un anumit nivel evolutiv ${ }^{1}$ este supusă unor dezbateri teoretice ample, în urma cărora i se decide direcția de dezvoltare ulterioară. În plus, dezvoltarea graiurilor populare este determinată de acțiunea unor cauze, în timp ce limbile de cultură evoluează în vederea unor scopuri ${ }^{2}$.

Limba populară sau vorbită este considerată de Ivănescu o varietate a unei limbi naționale, istoric constituite, prin natura ei diferită de limba de cultură. Cercetătorul ieșean precizează că atunci cînd vorbitorii se exprimă utilizînd variante ale limbii vorbite, ei se găsesc în ceea ce Ivănescu numește o „stare de natură” (Ivănescu, [s.a.], p. 11), în care activitatea lingvistică se realizează într-un mod oarecum inconștient, pe baza instinctelor lingvistice. Aici este vorba, de fapt, de lipsa proceselor de reflecție și de elaborare a expresiei lingvistice, întrucît exprimarea în limba vorbită este marcată de un înalt grad de spontaneitate, ce nu lasă prea mult timp vorbitorilor pentru selectarea unităților lexicale și a structurilor gramaticale. În această stare naturală, omul este complet sub influența tendințelor articulatorii. Starea opusă acesteia este considerată „starea de cultură”, ce caracterizează exprimarea prin intermediul limbii scrise. Cînd se găsește în această din urmă stare, vorbitorul are posibilitatea de a-și tempera înclinațiile dialectale, acceptînd normele dialectului impus ca limbă literară. Acceptarea acestor norme și aplicarea lor reprezintă procese voluntare, deci și conștiente, ceea ce demonstrează că evoluția limbilor literare depinde de factorul voință. Principala deosebire dintre graiurile populare și limbile literare este că evoluția fonetică se reduce la un proces de creație spontană în limbile vorbite și la un proces de imitație conștientă și voluntară în cazul limbilor de cultură.

În studierea unei limbi literare, Ivănescu este preocupat și de sursele sau bazele acesteia: pe de o parte, dialectele limbii în cauză, din care se preiau elemente populare și, pe de altă parte, alte limbi de cultură, care constituie surse de neologisme. Astfel, pentru limba română literară, se poate vorbi de baze dialectale (baze românești) și baze străine. Trebuie însă precizat că acțiunile acestor baze nu rămîn constante de-a lungul istoriei limbii de cultură, ci au o pondere variabilă, în funcție de dinamica rolului burgheziei în viața economică, politică și culturală a poporului în cauză.

În concepția lui Ivănescu, o limbă de cultură nu are un caracter unitar de-a lungul întregii ei existențe, acesta caracterizîndu-i doar faza de maturitate. Astfel, în etapa de început, limba literară se prezintă sub forma unor varietăți regionale, asemenea limbii vorbite, varietăți numite de cercetătorul ieșean dialecte literare (vezi infra). In cursul procesului de maturizare sau de modernizare, treptat, una dintre aceste varietăți se impune și celorlalte regiuni și se ajunge, în final, la configurarea și generalizarea unui singur sistem unitar de norme. Acest proces este unul complex, care se realizează prin consens al oamenilor de cultură, și care implică, de asemenea, și un transfer de particularități între dialectele existente.

\section{Limba literară veche}

În ceea ce privește istoria limbii române de cultură, aceasta este împărțită în două perioade: cea a limbii literare vechi și cea a limbii literare moderne. Începutul epocii limbii literare vechi este plasat de Ivănescu în secolul al XV-lea, cercetătorul arătînd că textele rotacizante, care sînt datate de filigrane în secolul al XVI-lea, sînt, de fapt, copii ale unor texte mai vechi, ce vor fi fost traduse în secolul anterior. În ceea ce privește aria geografică de care se leagă începutul scrisului românesc, Ivănescu susține că cele mai vechi texte, cele rotacizante, provin din zona Maramureșului. Meritul lor constă în faptul că au exercitat o puternică influență asupra limbii române scrise din toate celelalte regiuni, manifestată printr-o serie de elemente maramureșene care au fost impuse limbii române literare vechi: „limba textelor rotacizante, ca primă formă a limbii literare românești, a exercitat o influență covîrșitoare asupra limbii literare românești din epoca veche care i-a succedat, și, prin aceasta, asupra întregii limbi literare românești” (IVănescu, 2000, p. 572). Astfel, Ivănescu respinge opinia unor cercetători precum P.V. Haneș, Al. Rosetti, I. Bianu sau

\footnotetext{
${ }^{1}$ Este vorba de ceea ce Ivănescu consideră etapa modernă a unei limbi literare.

${ }^{2}$ În concepția lui Ivănescu, de regulă, scopul inovațiilor aduse limbii de cultură este aducerea unui plus de claritate în comunicarea literară.
} 
N. Cartojan, care au considerat că limba română literară actuală începe cu limba lui Coresi, acesta fiind văzut de ei drept întemeietorul limbii noastre de cultură. Profesorul ieșean arată că limba lui Coresi, la fel ca și cea a Scrisorii lui Neacșu, prezintă elemente de origine maramureșeană, cum ar fi io 'unde' sau corabii, forme care probabil nu existau atunci în graiul popular din Țara Românească, ceea ce dovedește influența limbii textelor rotacizante asupra scrisului muntenesc și, totodată, existența deja a unei tradiții scrise maramureșene.

Cum s-a sugerat mai sus, limba română literară veche se caracterizează prin absența caracterului unitar, în sensul că scrisul românesc prezenta diferențieri regionale, apărînd sub forma aşa-numitelor dialecte literare.

Prin dialecte literare, Ivănescu înțelege „variante teritoriale ale limbii literare române din epoca veche, caracterizate prin cîteva particularități fonetice și morfologice și prin particularităţi lexicale ceva mai numeroase" (Ivănescu, 1988, p. IX).

Dialectele literare reprezintă, așadar, varietăți diatopice ${ }^{3}$ utilizate fiecare într-o anumită regiune geografică pentru realizarea de texte scrise. Cele mai mari diferențe între ele se întîlnesc la nivel lexical. Deși această idee nu era nouă, în sensul că se mai vorbise despre dialecte literare (chiar dacă nu se utilizase această denumire) și anterior, Ivănescu este cel care a fundamentat și ilustrat în mod convingător această concepție, astfel încît, ulterior, teoria dialectelor literare a căpătat din ce în ce mai mulți adepți. Astfel, pentru epoca veche, savantul ieșean a identificat următoarele dialecte literare: dialectul crișean-maramureșean, rotacizant pînă în secolul al XVI-lea, dialectul bănățean, dialectul muntenesc și dialectul moldovenesc, cărora le este adăugat dialectul ardelean, utilizat la sud de Mureș.

\section{Epoca de tranziție}

În lucrarea Problemele capitale al vechii române literare, Ivănescu (1947) plasa sfîrșitul limbii literare vechi în secolul al XIX-lea; mai exact, el fixa ca limită superioară intervalul 1820-1830. Tot aici se menționa că sfîrșitul limbii literare vechi se datorează începutului limbii de cultură noi, pe care cercetătorul îl plasa în jurul anului 1780, cînd începea și cultura română modernă. În Istoria limbii române, concepția lui Ivănescu apare uşor modificată, în sensul că aici începutul epocii limbii moderne este decalat cu jumătate de secol mai tîrziu. Acum, el consideră că în perioada 1780-1830, persistă încă pe plan cultural „multe rămășițe ale trecutului" (Ivănescu, 2000, p. 630), iar cultura modernă devine dominantă abia începînd cu intervalul 1820-1830, cînd încep să activeze noii scriitori, oameni de cultură și oameni politici, în special în Moldova și Muntenia, toți însuflețiți de un spirit modern. Așadar, anii 1780 și 1830 delimitează o perioadă de tranziție, care a reprezentat, de fapt, o primă etapă de modernizare a limbii române literare. Acești ani nu mai sînt înțeleși ca limite punctuale ale limbilor veche și modernă, ci ei delimitează o perioadă de tranziție, în care cele două limbi sînt folosite în paralel ${ }^{4}$. Pînă în 1830, predomină încă limba literară veche, iar între 1830 și 1880 începe să se manifeste și, în cele din urmă, se impune limba literară modernă. Așadar, în anul 1780 nu începe direct limba literară modernă, ci „o fază nouă a limbii literare vechi și modernizarea sensibilă a limbii literare vechi” (Ivănescu, 2000, p. 632). Spre noua viziune asupra periodizării limbii de cultură, bazată pe existența unei perioade de tranziție, Ivănescu a fost condus de faptele de limbă cercetate între timp.

În această perioadă, se poate vorbi de două „stiluri” ale limbii scrise: o „limbă bisericească”, adică o limbă a textelor religioase, și o „limbă laică” sau „a literaturii laice” (Ivănescu, 2000, p. 628). Aceste două

\footnotetext{
${ }^{3}$ În Coseriu (2000), sînt distinse mai multe tipuri de variații ale limbii: diatopice (sau teritoriale), diastratice (în funcție de pătura socială căreia îi aparține vorbitorul) și diafazice (cu referire la stilurile funcționale).

${ }^{4}$ Concepția mai recentă a lui Ivănescu, care introduce perioada de tranziție de la limba literară veche la cea modernă, ni se pare mai apropiată de teoria coșeriană a schimbării lingvistice. Spre deosebire de Saussure (1998, p. 113), la care trecerea de la faptul vechi de limbă la cel nou era înțeleasă (sau cel puțin așa reieșea) ca „bruscă”, instantanee (datorită faptului că schimbarea era privită doar ca rezultat), Coseriu susținea ideea unei perioade de coexistență a celor două fapte de limbă, adică de utilizare a lor în paralel (schimbarea este văzută ca proces). Vezi, în acest sens și Coseriu (1977).
} 
varietăţi ale limbii literare încep să se contureze de la jumătatea secolului al XVIII-lea, anterior limba în care fuseseră scrise textele religioase și cele laice (adică literatura beletristică, actele) fiind aproximativ aceeași. Stilul laic este deschis influențelor populare fonetice și lexicale, mai ales spre sfirșitul secolului al XVIII-lea, cînd ia amploare literatura artistică (I. Budai-Deleanu, C. Conachi, Iancu Văcărescu), în timp ce limba religioasă se menține aproximativ uniformă peste tot, păstrînd un caracter în general muntenesc. Așadar, în secolul al XVIII-lea, limba literară se apropie semnificativ de limba poporului și de limba de cultură actuală prin textele beletristice. Limba literară de pînă atunci, fixată în special prin textele religioase, rămîne în uz în virtutea tradiției literare pînă la jumătatea secolului al XIX-lea, cînd se modernizează parțial și ea.

Începe să se scrie acum o limbă literară nouă, aproximativ limba actuală, care continuă limba laică din epoca anterioară. Noua limbă se caracterizează prin numeroase neologisme, însă ceea ce o deosebește de limba actuală este proveniența acestora. Neologismele împrumutate acum sînt de proveniență orientală în Principate (grecească, rusească, turcească) și germano-orientală în Ardeal (germană, latino-maghiară). Aspectul ei fonetic și morfologic „are un caracter vechi, deși ceea ce se spune prin ea este nou”, adică ea exprimă conținuturi noi, însă prin mijloace vechi: unii scriitori mai folosesc încă $-u$ după consoana finală, formele de imperfect ei cînta, ei vedea, perfectul compus la singular au fäcut, cuvinte ca a oblici 'a afla', predislovie 'prefață', expresii fixe ca mai vîrtos 'mai ales' etc. În ceea ce privește terminologia științifică și filozofică, majoritatea termenilor de pînă acum nu sînt neologici (împrumuturi directe), ci mai ales calcuri. Aproape toți aceștia încep să fie înlocuiți acum cu neologisme de origine latină sau romanică.

Schimbările lexicale de acum sînt impuse de burghezie, prin intermediul intelectualilor ei. Tot ea impune și schimbări în materie de fonetism și morfologie: practic, anumite particularități ale limbii vorbite de burghezie sînt impuse ca norme ale limbii literare, limba acesteia fiind mai apropiată de limba populară decît limba literară.

Un proces care se înregistrează în perioada de tranziţie în toate dialectele literare este muntenizarea, adică apropierea acestora de dialectul literar muntenesc prin adoptarea unor particularități specifice acestuia din urmă. În regiunea Ardealului, din nordul Mureșului și în Banat, apare tendința de înlocuire a lui $\breve{g}$ cu ž: leje, dejet, jurat, jurămînt, a înțeleaje, Mărjinime, Jioagiu, josu, jupînu etc. Avem de-a face aici cu o pătrundere a formelor populare în limba scrisă. Influența muntenească din Ardeal se manifestă și la nivel lexical, prin o serie de termeni de origine turcească și grecească, care intră în Ardeal în secolul al XVIII-lea: leafă, scopos etc.

Cauzele care au stat la baza acestui început de muntenizare sînt multiple: decadența culturii ardelenești, în condițiile opresiunii exercitate de austrieci, în numele catolicismului, ridicarea burgheziei, care nu cunoștea bine tradiția literară de pînă atunci și folosea, în consecință, numeroase elemente populare în scris. Ivănescu consideră că majorității tipăriturilor religioase muntenești li se datorează această apropiere. Potrivit lui, textele muntenești aveau un anumit prestigiu în ochii ardelenilor, în condițiile în care în Ardeal opresiunea catolică și condițiile grele de viață nu au mai permis aici tipărirea de cărți bisericești, ci au fost folosite cărțile religioase tipărite în Muntenia, mai ales în epoca lui Constantin Brîncoveanu și a lui Antim Ivireanu.

O altă cauză a muntenizării limbii literare din Ardeal, Banat, Crișana și Maramureș este atribuită de Ivănescu faptului că graiurile populare din aceste regiuni nu mai apăreau ca bază a limbii scrise, ca pînă atunci, datorită evoluției lor fonetice, care le făcuse să pară dialectale în raport cu limba scrisă mai veche (din Ardeal și din alte părți). Astfel, ardelenii ajung să considere literară nu limba scrisă (nici cea vorbită) de ei pînă atunci, ci limba scrisă muntenească, pe care acum, prin textele religioase, au ocazia să o cunoască. Ei au observat că limba scrisă, folosită de ei pînă atunci, era mai apropiată de cea muntenească decît graiul lor popular, care avea, printre altele, labialele palatalizate. În plus, dialectul literar muntenesc era folosit și în sudul Ardealului, ceea ce i-a făcut pe ardelenii din nord să considere că limba literară muntenească era cea folosită în Ardeal.

Schimbări ale normelor literare în direcție muntenească au loc și în Moldova la mijlocul secolului al XVIII-lea. Elemente ce caracterizau vechea tradiție de limbă maramureșeană sînt înlocuite acum cu forme ca: acum, aşa, curînd, țările, țării, șese, lege etc. Se mențin totuși fonetismele $\breve{g}$ și 
Moldova se manifestă și o influență a limbii populare asupra celei scrise. Transpunerea elementelor vorbite în scris nu s-a făcut direct, ci au fost folosite unele hiperliterarizări fonetice (forme hipercorecte): osinda 'osînda', seu 'său' (posesiv), trimețind, pîrire, pîrit, omorit etc. Această pătrundere a formelor populare în limba scrisă, care caracterizează și Muntenia, e determinată de apariția burgheziei, ai cărei reprezentanți, avînd acces la carte, practicau un scris mai neglijent, în care introduceau o serie de elemente populare. Ivănescu pune pe seama acestora iniţierea acestei apropieri a limbii scrise de cea vorbită.

De fapt, se formează acum ideea că limba literară se identifică cu dialectul muntenesc. Acest lucru se datorează, după Ivănescu, tot ridicării burgheziei. Originară din popor, aceasta utiliza labialele palatalizate (în Moldova și Ardeal) și, astfel, și-a identificat graiul cu labialele alterate ca dialectal, considerîndu-l pe cel cu labialele intacte ca literar (cel muntenesc). De aceea, Ivănescu consideră că palatalizarea labialelor a jucat un rol important în formarea percepției limbii muntenești ca limbă literară (Ivănescu, 1946-1947, p. 3839). Palatalizării i s-au adăugat și alte particularități ardelene și moldovenești, care au făcut ca graiurile de acolo să fie simțite ca dialectale: muierea sau africatizarea consoanelor $/ \mathrm{t} /$ și $/ \mathrm{d} /$, urmate de vocale palatale, confundarea consoanelor /t́t/și /d́d cu /ḱk și /ǵ/, închiderea lui /ă/ și /e/ finali la /îl și /i/.

Principalul factor care a dus la formarea acestei noi conștiințe lingvistice (a dialectului literar muntenesc ca limbă literară a românilor) a fost, prin urmare, ascensiunea în societatea românească a unor oameni din păturile inferioare. Noua conștiință s-a manifestat la început doar prin unele literarizări fonetice, dialectele literare păstrîndu-și, în linii mari, individualitatea. În jurul anului 1860, această conștiință a fost întărită şi de alţi factori: burghezia de limbă română cea mai dezvoltată era cea din Muntenia, iar capitala noului stat a fost stabilită la București. Ideea aceasta a dialectului muntenesc ca bază a limbii române literare a rezistat în conștiința oamenilor de cultură și a maselor pînă astăzi, cînd mulți încă consideră că a vorbi literar înseamnă a vorbi muntenește, chiar și cu elemente specific muntenești.

Caracterul de tranziție al limbii literare din perioada 1780-1830 este dat de apariția unor aspecte ale modernității. Unul dintre acestea vizează prezența neologismelor, necesare pentru exprimarea noilor conținuturi. În această privință, Ivănescu opinează că „natura unei limbi de cultură este dată de faptul că ea exprimă ideile culturii, că este caracterizată deci de natura vocabularului, care cuprinde neologismele necesare" (Ivănescu, 2000, p. 633), adică esența unei limbi literare este capacitatea de a exprima conținuturi culturale. Procesul de neologizare este acum abia la început, ceea ce se împrumutase pînă acum fiind insuficient, iar termenii introduși de unii scriitori nu se impuseseră încă. În plus, noii termeni aveau încă formele din limbile de proveniență, nefiind adaptați fonetic și morfologic limbii române. Uneori, limba „încă dibuia și era stîngace” (Ivănescu, 2000, p. 633), adică nu se crease încă o tradiție a utilizării noilor cuvinte.

În această perioadă, s-au înregistrat o serie de încercări de transformare a limbii române literare într-o limbă unică de cultură. Aceste preocupări au existat încă din secolul al XVII-lea, astfel încît, încercările de modernizare de acum se situează în continuarea celor vechi. Ivănescu consideră îndreptățită calificarea întregii perioade vechi a limbii și literaturii române începînd din secolul al XVII-lea drept modernă. El se referă la „umanismul român al epocii vechi” (Ivănescu, 2000, p. 633), admiţînd o dualitate a limbii și literaturii noastre: aceastea ar avea simultan caracter vechi și modern. Ivănescu consideră nepotrivită calificarea culturii românești drept veche, opusă celei moderne; mai corect ar fi, în concepția sa, să identificăm aspectele vechi și cele moderne ale acesteia: „Distincția prea netă între o cultură (sau literatură) veche și una nouă este artificială în cazul culturii române din secolul al XVII-lea și al XVIII-lea. Nu are rost să căutăm a defini cultura română dintre 1780 și 1830 ca veche sau ca nouă. Ea este evident, nouă, dar are și aspecte arhaice. Chiar epoca dintre 1730 și 1830 nu înseamnă o întrerupere totală a ceea ce se făcuse pînă pe la 1730. Din alte puncte de vedere, avem o perfectă continuitate de pe la 1630 și pînă la 1830" (Ivănescu, 2000, p. 633-634).

După cum s-a menționat deja, principalul mijloc de îmbogățire a lexicului de acum este neologizarea. Între 1750-1830, intră în limba literară numeroase neologisme de origine greacă, fapt cerut de „nevoile culturale ale epocii” (Ivănescu, 2000, p. 634). În paralel cu acestea, se mai înregistrează și acum calcuri lingvistice, ca în epoca veche, care îmbogățesc terminologiile științifice și filozofice, însă frecvența acestui 
din urmă procedeu scade.

Ivănescu afirma, pe bună dreptate, că apar acum multe neologisme de origine latină și romanică. S. Clain și G. Șincai au fost primii care au introdus masiv o serie de neologisme în română și le-au adaptat formal, unele dintre formele date de ei menținîndu-se pînă astăzi. Anterior, fuseseră preocupați de introducerea de neologisme și alți cărturari precum Cantemir, Dosoftei sau Milescu. Clain și alți oameni de cultură au considerat că neologismele trebuie „românizate”. În acest scop, ei au încercat să impună cuvintelor latine o parte din transformările care au caracterizat trecerea de la latina populară la română, ceea ce arată că aceste evoluții erau cunoscute: lat. experientia > speriință (sau speriență); la P. Maior: distinct > distinpt; la G. Șincai apare forma plîntu 'plantă' la I. Budai-Deleanu apar forme precum: lat. sanctuarium, it. santuario > sfintariu etc. Nu toate aceste modificări au fost acceptate de societate.

Intră acum în limba literară și multe elemente dialectale, proces favorizat de inexistența unei norme literare unice, clare și unanim acceptate. Scriitorii din fiecare regiune erau tentați să creadă că pot impune ca literare fapte de limbă (chiar și populare) din provincia lor, că pot ridica la rangul de limbă literară dialectul utilizat în regiunea lor, efectuînd unele literarizări. Dintre aceștia, pot fi amintiți P. Maior și C. Conachi. Cel dintîi a introdus fapte de limbă ca a mînă 'în mînă, se cîştigă 'se îngrijește' (de arme), specifice dialectelor crișean-maramureșean și ardelean și se poate spune că a creat o tradiție a limbii literare ardelenești. Costachi Conachi are meritul de a fi întemeiat în Moldova o tradiție a limbii literare scrise. El a introdus în limba literară o serie de moldovenisme populare: hojma 'mereu', mititele 'mici', paingul 'păianjenul'; de asemenea, a introdus în limba scrisă și cuvinte cu labialele palatalizate: se inghină (prezent, plural), chirotind, frînghie (în locul echivalentului ardelenesc frîmbie), inghie (plural) etc. Conachi a folosit și unele neologisme, cărora le-a dat o adaptare fonetică specială (ex. plîntă). Cultivarea limbii scrise în Moldova va fi continuată de G. Asachi. Majoritatea particularităților de limbă de la scriitorii de atunci nu sînt inovații proprii, ci aparțin intelectualității, reprezentate în special de boieri (Ivănescu, 2000, p. 636).

Ivănescu precizează că, pînă la 1830, limba literară a fost influențată mai mult de limbile greacă, rusă și germană, decît de latină, franceză și italiană. De aceea, unele cuvinte romanice au intrat în limba română prin filieră greacă, rusă sau germano-maghiară. Acestei filiere i se datorează nu doar aspectul fonetic, ci și unele sufixe, care nu apăreau în limba de origine: a recomandarisi (prin filieră greacă), a recomăndălui (prin filieră germano-maghiară). După 1830, acestea vor fi înlăturate, la recomandarea lui I. Heliade Rădulescu, în favoarea formelor fără sufix.

Tot de perioada de tranziție sînt legate, după Ivănescu, și începuturile literaturii noastre artistice moderne. Anterior, se creaseră puține opere artistice (puțină poezie, prin Dosoftei, M. Costin, și puțină proză, prin D. Cantemir), care, însă, nu reușiseră să impună o tradiție a literaturii beletristice, singura tradiție existentă atunci fiind cea a limbii bisericești. Poezia care începe să se scrie acum este una stîngace (Iannache Văcărescul, Ioan Cantacuzino), însă se remarcă un progres la nivelul tehnicii verbale în creațiile lui C. Conachi și Iancu Văcărescu. Cu toate acestea, lipsa de tradiție a limbajului artistic face ca limba poeziei lor să fie neadaptată conținutuluii (vezi Ivănescu, 2000, p. 635).

Ceea ce îl individualizează pe Ivănescu în raport cu alți cercetători ai limbii române literare este preocuparea sa și pentru limba de cultură a românilor suddunăreni, care a fost, în general, neglijată. Astfel, el a acordat atenție și dezvoltării limbii de cultură a aromânilor. Limba literară a acestora a apărut în secolul al XVIII-lea, și a reprezentat creația burgheziei, spre deosebire de dacoromâni, unde apariția limbii de cultură s-a datorat aristocrației. O serie de cărturari aromâni, la influența celor ardeleni, au început să scrie în macedoromână cu litere latine, în loc de grecești și au introdus inovații în sensul apropierii de dialectul dacoromân, obiectivul lor fiind realizarea unei singure limbi scrise pentru toți românii. Activitatea lor era, așadar, animată de un puternic sentiment naționalist. Teoreticianul unificării limbii scrise a aromânilor și dacoromânilor a fost Gheorghe Constantin Roja, care a respins scrierea cu litere grecești, pledînd pentru

${ }^{5}$ I. Budai-Deleanu chiar deplînge în Prologul la Țiganiada „neajungerea limbii”, adică insuficiența mijloacelor de expresie de care dispunea limba. 
grafia latină. Întrucît tendințele naționaliste ale aromânilor au fost considerate periculoase pentru greci, Patriarhia din Constantinopole a reprimat orice manifestări de acest gen.

Prin urmare, Ivănescu renunță în ultima parte a activităţii sale la delimitarea şi distingerea radicală a perioadei limbii literare vechi de cea modernă, viziune care îi caracteriza începutul carierei de cercetător, și preferă să analizeze, în cazul fiecăreia dintre acestea, elementele specifice „vechimii”, respectiv modernităţii limbii de cultură. În acest fel, demersul său reușește să evidențieze mai bine caracterul de tranziție al epocii 1780-1830, prin situarea tuturor fenomenelor petrecute acum între „vechi” și modern, între desuet și inovator.

\section{Limba literară modernă}

Din 1830, începe ceea ce Ivănescu numește a doua perioadă a modernizării limbii române, care ține pînă la Războiul pentru Independență (1878), de cînd se poate vorbi de limba literară actuală. Și în această epocă (1830-1878), se menține caracterul de tranziție al limbii literare, însă acum se accentuează modernizarea și fixarea limbii de cultură unitară, în paralel cu eliminarea elementelor specifice limbii vechi.

Pînă în 1830, limba literară era folosită mai mult de aristocrați; această dată marchează începutul unei noi etape a istoriei limbii noastre de cultură, etapă în care limba literară este preluată ca mijloc de expresie de burghezie, aceasta devenind „însăși organismul social care susţine limba literară” (Ivănescu, 2000, p. 647). Trebuie precizat că nu este vorba de burghezie în întregul ei. Nu negustorii sau meseriaşii, ci intelectualii care s-au ridicat din această categorie (profesori, judecători, funcționari administrativi, mlitari, avocați, medici, ingineri etc.) au utilizat și determinat noua evoluție a limbii de cultură. Această intelectualitate este acum mai numeroasă decît înainte, cînd fusese constituită aproape numai din clerici și boieri, rolul acestora din urmă reducîndu-se drastic în noua epocă. Noua intelectualitate ridicată din interiorul burgheziei și-a însuşit limba literară existentă (cu diferenţieri dialectale, mai ales în plan lexical) și a cultivat-o în noile condiții social-economice. Această „preluare” a limbii literare de către burghezie are ca efect anumite schimbări, care duc la constituirea limbii literare moderne. Afirmarea burgheziei coincide și cu începutul modernizării Țărilor Române și cu cel al stabilirii multor relații cu Occidentul și cu Rusia.

După 1830, sînt înlăturate unele elemente fonetice, morfologice și sintactice specifice limbii vechi, iar limba vorbită a burgheziei influențează tot mai mult limba scrisă. Între 1859 și 1870, se impune limba intelectualităţii burgheziei ca limbă literară și își definitivează particularitățile esenţiale. Tot atunci este înlocuit alfabetul chirilic, specific limbii vechi, cu cel latin.

Potrivit lui Ivănescu, crearea noii limbi „a fost un proces sufletesc” (Ivănescu, 2000, p. 656), nu unul mecanic. Principalul rol l-au avut scriitorii, care, luînd ca model limbile altor culturi, au depus mari eforturi de a transforma limba veche într-un instrument adecvat de expresie a ideilor omului modern. Însă mijloacele de realizare a acestei transformări variau de la un scriitor la altul și de la o provincie la alta. De aceea, s-au conturat în această epocă mai multe curente de limbă, toate însă îndreptate către aceeași țintă: crearea unei limbi literare unitare ${ }^{6}$ a poporului român. Așadar, obiectivul era comun, doar căile de realizare a lui erau diferite. Dintre toate curentele de limbă, s-au impus, cum era și normal, cele bazate pe bun simt, adică cele care nu se îndepărtau prea mult de limba poporului. Modalitățile de diseminare a noilor particularități erau extrem de diverse: traduceri, opere originale, manuale școlare, texte de legi, presă, gramatici și dicționare. Noile fapte de limbă erau răspîndite prin aceste mijloace de către oamenii de cultură cu cea mai mare autoritate, ele fiind apoi însuşite și de masele de intelectuali.

Trecerea de la limba veche la cea nouă reprezintă, după Ivănescu, un fenomen complex, care include două procese: modernizarea și unificarea limbii literare. Fiecare dintre acestea ridică cîte o problemă: interesează modul în care s-a produs modernizarea, adică transformarea limbii vechi într-un instrument adecvat de expresie a ideilor moderne, care să rămână, în acelaşi timp, cît mai apropiat de graiul poporului; în privința celui de-al doilea proces, este important cum s-a produs unificarea limbii literare, știind că

\footnotetext{
${ }^{6}$ Pentru a desemna limba literară unitară, Ivănescu mai foloseşte sintagma de limbă naţională.
} 
s-a pornit de la o limbă literară diferențiată regional, iar tentativele de modernizare au fost în principal divergente.

Problema adaptării limbii literare la conținuturile moderne s-a acutizat în condițiile înființării școlilor elementare și secundare în Muntenia și Moldova, în condițiile formării unui public cititor relativ numeros și pe fondul apariției unei prese laice. Intelectualii vremii erau de acord că nu se putea pleca de la un dialect popular, ci că punctul de pornire trebuia să fie limba literară de pînă atunci. Opinii divergente apăreau însă în privința modificărilor care trebuiau aduse în vederea noii limbi de cultură, întrucît nimeni nu era dispus să renunțe la particularitățile dialectale din provincia sa.

În Muntenia, principalul rol în înnoirea limbii literare l-a avut I. Heliade-Rădulescu. În prefaţa de la Gramatica românească (1828), el respinge limba și ortografia de pînă atunci pentru formele greoaie ale unor neologisme (verbe terminate în -arisesc/-erisesc și -ăluiesc) și unele elemente inutile ale grafiei chirilice (semne în plus, spirite, accente). De aceea, el a încercat o reformare a limbii și ortografiei românești. Heliade-Rădulescu a folosit în scris vechiul dialect literar muntenesc, căruia i-a adus unele modificări fonetice, morfologice și lexicale, propuse de C. Negruzzi, care au fost, în general, acceptate. De asemenea, a renunțat la unele arhaisme din limba literară anterioară și a preluat elemente și din limba scriitorilor din alte dialecte decît cel muntenesc.

Mai exact, Heliade-Rădulescu a introdus unele elemente populare precum: forma $a$ a auxiliarului perfectului compus la persoana a III-a singular, în loc de au, formele - or și -ar, în locul fonetismelor vechi etimologice - oriu (din lat. -orius) și -ariu (din lat. -arius) în cuvinte ca trecător, ajutor, morar, înlocuind forme mai vechi precum trecătoriun, ajutoriu , forma nearticulată a pronumelui relativ care în loc de carele și carea, pl. carii și carele. A menținut numeroase elemente dialectale muntenești, care au fost ulterior eliminate din limba literară: genitivul singular a casi 'a casei', nominativul plural urși 'urșii', păste 'peste', $d \breve{a}$ 'de' etc. În privința tratamentului neologismelor latino-romanice, Heliade a susţinut modificarea lor, ca și reprezentanții Școlii Ardelene, astfel încît aspectul latin să fie adaptat conform evoluției fonetice românești: $-t i a>-t ̦ a ̆,-e ́ n->-i n-$ etc.

Criteriile de îmbogățire a limbii pe care le aplica Heliade-Rădulescu erau: „respectarea geniului și naturii limbii” (Ivănescu, 2000, p. 661), prin împrumutarea neologismelor din limbi înrudite și prin adaptarea lor și „vigoarea și frumusețea limbii” (Ivănescu, 2000, p. 661-662). În acest scop, el recomanda renunțarea la formele lungi și greoaie, cum ar fi pluralele neutre în -uri, în locul cărora le prefera pe cele în $-e$. Limba elaborată de el a fost acceptată şi însuşită doar de burghezia cultă din Muntenia, care i-a acceptat și italienismele de după 1840. Heliade-Rădulescu a susţinut însă, în mod greșit, unitatea limbii bisericești, neluînd în calcul și textele religioase moldovenești și ardelenești din secolul al XVII-lea, ci doar pe cele ardelenești și moldovenești din secolul al XVIII-lea, care au, într-adevăr, un aspect fonetic muntenesc.

În Moldova, rolul de inovator al limbii literare i-a revenit lui G. Asachi. Acesta a păstrat particularitățile dialectului literar moldovenesc din epoca veche, cu $\breve{g}$ în loc de $j: \breve{g} o c, \breve{g} u d e c$ etc. În ceea ce privește tratamentul neologismelor, Asachi a urmat modelul limbii ruse: scria imperie pentru imperiu (rus. imperija) și dădea acestor substantive genul feminin. A folosit și el unele italienisme ca drit 'drept' și creații proprii ca a înainti 'a înainta'. În locul sufixului -itate, care apărea la ardeleni și la Heliade-Rădulescu, a folosit forma -ità, de origine italiană (ex. cualità).

În Ardeal şi Banat, unii cărturari, precum T. Cipariu, au continuat limba lui P. Maior, în timp ce alții, ca G. Barițiu, au urmat linia scrisului celorlalți scriitori ardeleni de pînă la 1825. Au existat și aici unele exagerări în sens latinizant din partea lui A. T. Laurian și I.C. Massim, care au introdus numeroase modificări lexicale latinizante, ce au dus la o limbă artificială.

Un rol nu mai puțin important $l$-au avut scriitorii moldoveni din generaţia 1840, reprezentanți ai curentului istoric și popular: C. Negruzzi, M. Kogălniceanu, V. Alecsandri, A. Russo ș. a. Aceștia au fost grupați în jurul revistelor „Dacia literară”, „Arhiva românească”, apoi și „Propăşirea”. Limba lor prezenta anumite diferențe faţă de cea a lui Asachi: ei au folosit unele particularități literare moldovenești impuse de Asachi (a inainti, studie - substantiv feminin-, drit 'drept', cualità etc.), dar le-au respins pe altele mai curioase, apropiindu-se de limba muntenească din punct de vedere fonetic, morfologic și lexical. 
În condițiile în care publicațiile periodice românești din Ardeal foloseau o limbă asemănătoare fonetic cu cea a lui Heliade-Rădulescu, scriitorii moldoveni de la 1840 au considerat de datoria lor să elimine unele particularități moldovenești. Astfel, limba revistei „Dacia literară” (1840) și a altor cărți și traduceri publicate atunci seamănă foarte mult cu cea a lui Heliade-Rădulescu.

Scriitorul care a inițiat procesul de muntenizare în Moldova a fost C. Negruzzi, sub influența lui Heliade. În primul său text cu muntenisme (o traducere din Maria Tudor a lui Victor Hugo), Negruzzi a înlocuit formele terminate în -toriu, -oriu, -ariu cu -tor, -or, -ar, forma au cu a pentru auxiliarul de persoana a III-a singular a perfectului compus, $\hat{i} i$ cu $e$ 'este' etc. Toate aceste muntenisme apar și în scrierile următoare ale lui Negruzzi. Mai mult, el i-a convins și pe scriitorii mai tineri care se afirmau atunci în Moldova (mai ales pe M. Kogălniceanu și V. Alecsandri) că unificarea limbii române literare nu se poate realiza decît prin renunțarea de către moldoveni la unele elemente dialectale specifice lor, în favoarea celor muntenești. În consecință, acești scriitori tineri au întemeiat revista „Dacia literară”, între ale cărei obiective era și unificarea limbii române literare. Această direcție a avut și contestatari în Moldova, dintre care cel mai cunoscut a fost G. Săulescu, care a polemizat pe această temă cu Heliade-Rădulescu. Deși au fost primii care au renunțat la unele elemente literare moldovenești, scriitorii moldoveni de la „Dacia literară” au respins și unele forme muntenești ca şase, şapte, păşaşte, jale, slujaște etc.

Alt scriitor care a avut un rol important în formarea limbii române literare de după 1848 a fost V. Alecsandri. El nu a urmat integral linia lui Negruzzi, muntenizarea sa fiind fiind mult mai redusă decît a acestuia din urmă: pînă prin 1875, el a folosit moldovenisme ca $\breve{g}$ în loc de $j$ în cuvinte ca $\breve{g} o c, \breve{g} u d e c$, -să pentru -se (esă 'iese'), să 'se' (pronume), pre 'prea' etc. A acceptat însă formele cu -tor, -or, -ar și a reintrodus în limba literară din Moldova forme muntenești precum şase, şapte, şarpe, jale, care mai fuseseră introduse și în secolul al XVIII-lea. În concepția lui Ivănescu, aceste forme se vor fi impus prin scrierile sale în limba literară unificată întrucît alte muntenisme pe care el nu le-a folosit au rămas neliterare (păşaşte, slujaşte etc.).

Muntenii au renunțat și ei, între 1860-1880, la unele elemente ale dialectului lor literar, pentru a imita limba lui Alecsandri. Astfel, s-a realizat o fuziune a dialectelor literare muntenesc și moldovenesc din 1830-1880, însă, chiar și după aceea, au mai rămas unele diferențe, mai ales la nivel lexical.

Scriitorii moldoveni care s-au afirmat după 1859 (Hasdeu și junimiștii) au acceptat și impus unele elemente ale graiului muntenesc. Astfel, au dispărut din limba scrisă moldovenească forme ca a înainti, studie, drit etc. și s-au introdus forme ca a făcut (singular) în loc de au făcut, ei făceau în loc de ei făcea (specific limbii vechi). Formele moldovenești și ardelenești pășește, slujește au fost acceptate în Muntenia mai întîi de Cezar Bolliac, I. Ghica și A. Odobescu. În schimb, moldovenii de la Junimea au acceptat forme muntenești ca joc, judec, care existau deja în limba scrisă a ardelenilor.

În Ardeal, este acceptată limba în curs de fixare în Moldova abia de către scriitorii care debutează între $1870-1880$.

Unificarea limbii literare, deși nici acum nu e totală, se produce, după Ivănescu, pînă pe la 1880 . Aceasta nu a însemnat înlăturarea dialectelor literare moldovenesc și ardelenesc în favoarea celui muntenesc, care, după unii cercetători, s-ar fi impus ca limbă literară pentru toți românii, ci a constat într-un amestec (în sensul unui compromis) al dialectelor muntenesc și moldovenesc-ardelenesc-bănățean.

Tendința centrală din cadrul procesului de modernizare a fost latinizarea sau romanizarea lexicului. Aceasta a presupus introducerea în limba română literară a unui aflux masiv de elemente neologice latine și romanice și, în același timp, eliminarea elementelor slave, grecești și maghiare. Acest curent s-a manifestat în întreaga intelectualitate românească. Maiorescu, de exemplu, a militat pentru o „reintegrare a poporului român și a culturii sale în lumea modernă, dar, în primul rînd, între popoarele și culturile neolatine (romanice)" (Ivănescu, 2000, p. 672).

Latinizarea s-a manifestat nu doar la nivel lexical, ci şi sub aspect fonetic. Este vorba de adaptarea formală a neologismelor la specificul limbii române. De regulă, neologismele au fost „românizate fonetic” (Ivănescu, 2000, p. 677), în sensul că li s-au impus unele schimbări fonetice pe care le-ar fi suferit dacă ar fi fost moștenite din latină. Acest procedeu apare la toți latiniștii, însă a fost aplicat abuziv de scriitorii 
ardeleni (Clain, Șincai, I. Budai-Deleanu), ajungîndu-se la situații în care cuvintele rezultate în urma acestor transformări erau identice formal cu cele moștenite din latină pe cale populară, care însă aveau alt sens. Din cauza omofoniei create, ele nu au fost acceptate de intelectualitatea de după 1880-1900. $\mathrm{Cu}$ toate acestea, unele dintre aceste forme rezultate prin adaptări care nu erau necesare, ci se făceau din motive ideologice, s-au impus: un exemplu ar fi cel al neologismelor latinești cu terminația -tia, care a fost modificată la $-t ̦ a ̆$. Impunerea acestei ultime forme a fost sprijinită de faptul că în limbile romanice occidentale existau terminații asemănătoare: it. $-z z a$, fr. $-c e$, sp. $-z a$.

O altă trăsătură importantă a limbii literare moderne se referă la înlocuirea alfabetului chirilic cu cel latin. Aceasta nu s-a realizat direct, ci prin intermediul unor alfabete de tranziție. Iniţiativa introducerii unui asemenea alfabet i-a aparținut lui I. Heliade-Rădulescu, care, în Gramatică românească (1828), propunea înlocuirea anumitor semne chirilice și eliminarea accentului și a spiritelor, care oricum nu aveau corespondent în pronunția românească. Reforma ortografică propusă de el a însemnat o adaptare a alfabetului chirilic la sistemul fonetic al limbii române. Înlăturarea totală și definitivă a alfabetului chirilic se face abia în 1860 în Muntenia și în 1863 în Moldova.

După ce scriitorii români au început să utilizeze alfabetul latin în deceniul al cincilea, s-au conturat două tendințe, care aparțineau de fapt unui singur curent: etimologismul. Prima era tendința latinistă, ai cărei adepți (între care se remarcă Cipariu) notau acele sunete care nu existau în latină $(/ \breve{a} /, / \hat{\imath} /, / s, /, / t ̦ /$, /d̦/) prin caractere sau grupuri de caractere latine, fără semne diacritice. De exemplu, /ș/ se reda prin $s$ sau $s i, / t ̦ /$ prin $t$ sau $t i, /$ d̦/ prin $d$ sau $d i$. Această manieră de notare nu s-a impus. A doua tendință a fost iniţiată de Heliade-Rădulescu şi era singura raţională. Potrivit ei, se folosea o notare fonetică, însă nu în raport de o literă pentru un fonem, ci în sensul că nota un fonem prin mai multe litere, cele din limba de origine, combinate cu semne diacritice. Așadar, aceasta era o scriere simultan fonetică și etimologică. Potrivit ei, /c/ se reda în scris prin $q u$, atunci cînd etimonul latin al cuvîntului vizat conținea secvența qu, diftongul /ea/ se reda prin é, iar /oa/ prin ó, / ke/și / ki/ prin che, respectiv chi. Maniera de notare care s-a impus a fost cea a lui Heliade-Rădulescu, care a fost acceptată de scriitori ca Odobescu, Bolliac, Hasdeu și Alecsandri. În 1869, în urma a numeroase dezbateri, Societatea Academică Română votează sistemul etimologic al celor care utilizau diacritice, în detrimentul latiniștilor. Abia în 1881, Academia va accepta ortografia fonetică, ceea ce va însemna renunțarea la etimologismul latinizant, „menținîndu-se doar un etimologism în marginile limbii române" (Ivănescu, 2000, p. 690).

Modernizarea limbii române a implicat și dezvoltarea unui nou limbaj poetic sau „stil înalt”. Acesta s-a format, după Ivănescu, în opoziție cu limbajul obișnuit, din sinonimele pe care limba le pune la dispoziție. De aceea, limbajul poetic „va varia în raport cu variațiile limbajului obişnuit” (Ivănescu, 2000, p. 703), evoluția celor două fiind paralelă. Astfel, dacă limbajul obişnuit s-a îmbogăţit semnificativ în secolele al XVIII-lea și al XIX-lea, în special după 1830, și limbajul poetic a cunoscut o amplă dezvoltare în secolul al XIX-lea, cînd începe să se scrie la noi o bogată poezie cultă. Un model important al poeților a fost limbajul poetic popular, care a fost preluat și valorificat după 1840 , în condițiile redescoperirii și culegerii poeziei populare, o contribuție importantă avînd aici V. Alecsandri.

În concepția lui Ivănescu, limbajul poetic românesc are trei surse de bază: limba literară veche, neologismele (ca parte a limbii literare moderne) și dialectele populare. Elemente ale acestor trei surse căpătau valoare poetică atunci cînd ele intrau în opoziție cu termenii uzuali. De exemplu, cînd un cuvînt uzual în limba veche precum slovă era înlocuit cu un neologism ca literă în limbajul obișnuit, cel dintîi dezvolta o valoare poetică, și aceasta pentru că se opunea termenului uzual (literă). Desigur, valoarea poetică era doar din perspectiva modernilor. Într-un mod similar au devenit poetici fință în raport cu lume și existență, neființă față de neant, stih față de vers, crăiasă în raport cu regină etc.

În ceea ce privește cultura aromână, Ivănescu subliniază o preocupare și o implicare a românilor din Principate (din partea unor personalități ca C.A. Rosetti, D. Bolintineanu, Cezar Bolliac, Cristian Tell, Dimitrie Cazacovici, Dinu Sideri sau Iordache Goga) în vederea generalizării învățămîntului în limba română la aromâni. În a doua jumătate a secolului al XIX-lea, sînt înființate școli românești în Macedonia pentru menținerea identității culturale a acestei ramuri românești. 
După 1878, pe teritoriul dacoromân, se dezvoltă o intelectualitate mult mai numeroasă decît înainte prin faptul că acum ea include și reprezentanți proveniți din rîndurile țărănimii, unii dintre aceștia fiind şi scriitori (B. Ștefănescu Delavrancea, Al. Vlahuță, I. Creangă, I. Slavici, G. Coșbuc ș.a.). Acest fapt este coroborat cu înființarea a numeroase licee și a universităților din Cluj și din Cernăuți. Toate acestea vor asigura asigura noii limbi literare o mai mare stabilitate și vor contribui la înflorirea culturii românești de la începutul secolului XX, care va atinge o culme în perioada interbelică. Pe lîngă crearea unei literaturi de mare valoare artistică de către scriitori precum M. Eminescu, I. Creangă. I. L. Caragiale, M. Sadoveanu, T. Arghezi, L. Rebreanu, I. Barbu, L. Blaga, sau Al.A. Philippide, dezvoltarea culturii românești va fi susținută și de bogata activitate științifică a unor oameni de știință și filozofi ca B. Petriceicu Hasdeu, T. Maiorescu, C. Dobrogeanu Gherea, V. Conta, Gr. Tocilescu, A.D. Xenopol, N. Iorga, Alexandru Philippide, C. Rădulescu-Motru, P.P. Negulescu, M. Dragomirescu, G. Ibrăileanu, E. Lovinescu, Ov. Densusianu, G. Ibrăileanu, E. Lovinescu, V. Pârvan, S. Pușcariu etc.

După 1878, limba română literară intră într-o fază de stabilitate ${ }^{7}$ și de unitate fără precedent. Singura dezvoltare care se mai produce acum are loc în plan lexical și artistic. Fiind definitiv fixată, limba literară nu mai suferă acum modificări fără sens ale elementelor sale, ci ea se schimbă doar cu scopul exprimării unor noțiuni noi și al realizării unor valori artistice. Evoluția lexicală este legată acum de progresele din domeniul culturii materiale și spirituale a poporului român.

Se creează acum un așa-numit „stil intelectual” (Ivănescu, 2000, p. 734), caracterizat de o serie de neologisme care sînt împrumutate din limbi occidentale. Acestea sînt cunoscute în special de intelectuali, care le acceptă, deși limba română are deja termeni pentru desemnarea acelorași realități: benign, cotidian, decențăa, depravat, depravare, impecabil, impertinent, rural, rustic, urban etc. Aceștia sînt sinonimi cu termeni binecunoscuți, ce caracterizează uzul cotidian, nepretențios: blînd, zilnic, cuviincios sau politicos, cuviință, stricat sau desfrînat, färă păcate sau färă cusururi, obraznic, țărănesc sau sătesc, orăşsenesc etc. S-a ajuns astfel la o „dedublare a limbii literare românești” (Ivănescu, 2000, p. 703), asemănătoare cu cea din epoca latiniștilor și italieniștilor, numai că acum, noii termeni nu au tendința de a-i înlocui pe cei deja existenți, ci, pur și simplu, ei dau o notă de eleganță și de distincție exprimării.

În ceea ce privește plasarea ei în context european, Ivănescu consideră că limba română literară poate fi apropiată de celelalte limbi de cultură romanice prin faptul că, în etapa de formare, a împrumutat numeroase neologisme din latină, din nevoia exprimării unor idei culte. Dezvoltîndu-se mai tîrziu decît corespondentele ei europene, limba noastră literară și-a reconstituit lexicul latin, pierdut prin înlocuirea, de-a lungul istoriei ei, cu elemente non-latine. Ceea ce deosebește limba română de cultură de limbi precum cele slave, germana sau maghiara este ponderea ridicată a neologismelor pe baza cărora limba noastră și-a dezvoltat lexicul, mai ales în epoca modernă, spre deosebire de limbile respective, care au avut ca mijloc predilect de îmbogățire lexicală calcul.

\section{Concluzii}

Ivănescu este un savant ce rămîne consecvent principiilor sale de cercetare a diacroniei limbii. Ideile sale de ordin teoretic cu privire la evoluția unei limbi și la modul în care aceasta ar trebui studiată se regăsesc și în partea aplicativă a scrierilor lui.

Astfel, Ivănescu a pledat pentru despărțirea studiului istoriei limbilor populare de cel al istoriei limbilor de cultură. Această separare, impusă teoretic în baza faptului că cele două varietăți (populară şi literară) ale unei limbi naționale sînt considerate ca fundamental distincte, fiind dirijate de acțiunea unor factori diferiți, se regăsește în scrierile sale cu caracter diacronic. Ivănescu este, prin urmare, materialist, idealist şi sociolog, cînd cercetează istoria limbilor populare și idealist atunci cînd se ocupă de istoria limbilor de cultură.

În aceste condiții, un element de modernitate, care ridică, credem noi, Istoria lui Ivănescu deasupra altor istorii lingvistice este legat tocmai de bazarea ei pe un număr de principii riguroase, fapt ce conferă o

\footnotetext{
${ }^{7}$ În viziunea lui Ivănescu, evoluția unei limbi literare include o perioadă de formare, urmată de una de stabilitate.
} 
claritate sporită a materialului prezentat și facilitează, într-o măsură considerabilă, înțelegerea acestuia de către cititori. Am spune că, datorită acestei organizări, această operă este accesibilă chiar și celor mai puțin iniţiați în studiul istoriei limbii, fără ca aceasta să însemne pierderea (sau diminuarea) ținutei științifice a lucrării.

În ceea ce privește istoria limbii noastre de cultură, începutul acesteia este plasat de Ivănescu în secolul al XV-lea, odată cu apariția primelor texte scrise în limba română, anume, textele rotacizante. Istoria limbii române literare este împărțită în două perioade, una veche și una modernă, însă ceea ce este distinctiv pentru teoria lui Ivănescu este ideea existenței dialectelor literare în perioada veche, adică faptul că limba scrisă a fost fragmentată regional pînă în secolul al XIX-lea, prin aceasta, cercetătorul contrazicînd ideea unităţii limbii literare în epoca veche, susţinută de alți lingviști (în special cei bucureșteni). Cercetătorul are, prin urmare, meritul de a fi fundamentat perspectiva dialectală și în studiul limbii literare, anterior, aceasta fiind aplicată la noi mai mult limbii populare.

Valoarea concepției lui Ivănescu stă și în complexitatea ei, dată de faptul că a fost construită pe baza unor idei ce provin din numeroase doctrine lingvistice. Subliniem că nu este vorba de o simplă preluare a acestor idei și de aducerea lor la un loc, ci Ivănescu le-a reinterpretat, le-a reformulat și le-a „articulat” între ele, construind astfel o concepție lingvistică originală. $\mathrm{Nu}$ mai puțin important, savantul ieșean nu s-a limitat la un studiu strict lingvistic, ci a introdus în cercetarea sa numeroase informații din mai multe discipline științifice (istorie, sociologie, antropologie), ceea ce dă scrierilor sale un caracter interdisciplinar, erudit și chiar enciclopedic.

\section{Bibliografie}

Coseriu, E. (1977). Sincronie, diacronie și istorie, traducere de Nicolae Saramandu, Editura Enciclopedică, București.

Coseriu, E. (2000). Limba funcțională, în vol. Lecții de lingvistică generală, Editura ARC, Chișinău, p. 263.

Gheție, I. (1975). Baza dialectală a românei literare, Editura Academiei Republicii Socialiste România, București.

Ivănescu, G. (1946-1947). Istoria limbii române în lumina materialismului dialectic, în „Buletinul Institutului de Filologie Romînă“, vol. XIII-XIV, Iași, p. 3-48.

Ivănescu, G. (1947). Problemele capitale ale vechii române literare, în „Buletinul Institutului de Filologie Romînă”, vol. XI-XII, Iași, p. 1-412.

Ivănescu, G. (1988). Studii de istorie a limbii române literare, Junimea, Iași, p. IX.

Ivănescu, G. (2000). Istoria limbii române, Junimea, Iași.

Ivănescu, G. ([s.a.]). Istoria graiurilor populare și istoria limbilor literare, text inedit, aflat la Biblioteca Filialei Iaşi a Academiei Române, fondul Ivănescu, p. 11.

Saussure, Ferdinand de (1998). Curs de lingvistică generală, Polirom, Iași. 